\title{
MODEL RANCANGAN PENGUKURAN KINERJA DENGAN PENDEKATAN METODE INTEGRATED PERFORMANCE MEASUREMENT SYSTEM
}

\author{
Nurul Aziza ${ }^{1}$, Yusuf Eko Nurcahyo ${ }^{2}$
}

${ }^{1}$ Teknik Industri, Fakultas Teknik

Universitas Maarif Hasyim Latif, Sidoarjo, Indonesia

e-mail : nurul_aziza@dosen.umaha.ac.id

2Teknik Manufaktur

Politeknik 17 Agustus 1945 Surabaya, Surabaya, Indonesia

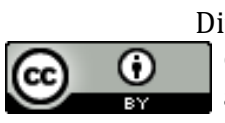

Diterima: 23 Maret 2017. Disetujui : 19 Mei 2017. Dipublikasikan : 1 Juni 2017

(C)2017 -TESJ Fakultas Teknik Universitas Maarif Hasyim Latif. Ini adalah artikel dengan akses terbuka di bawah lisensi CC BY 4.0 (https://creativecommons.org/licenses/by/4.0/)

\section{ABSTRAK}

P2KP adalah Program penanggulangan Kemiskinan di Perkotaan atas prakarsa Departemen Pekerjaan Umum yang kemudian berganti nama menjadi PNPM Mandiri Perkotaan dimana program ini meliputi tingkat kelurahan, kecamatan, kabupaten dan propinsi. Dalam prakteknya, pelaporan kinerja PNPM Mandiri ini masih didasarkan pada laporan review Partisipatif dari masyarakat sebagai bentuk pertanggungjawabannya dimana harus dituntut transparan dan akuntabilitas.

Sistem pengukuran kinerja sepeti itu tidak bisa mengukur kinerja organisasi secara pasti dan terukur nilainya. Oleh sebab itu dibuatlah rancangan sistem pengukuran kinerja organisasi dengan pendekatan Integrated Performance Measurement Systems yang mengintegrasikan semua elemen yang terlibat didalam organisasi.

Berdasarkan rancangan pengukuran kinerja tersebut dan disimulasikan didapatkan hasil kinerja organisasi dan hasilnya berupa nilai pencapaian yang dapat terukur.

Kata Kunci : Integrated Performance Measurement System, Pengukuran Kinerja, PNPM Mandiri Perkotaan

\section{PENDAHULUAN}

Program Penanggulangan Kemiskinan di Perkotaan (P2KP) dilaksanakan sejak tahun 1999 sebagai upaya pemerintah untuk membangun kemandirian masyarakat dan pemerintah daerah dalam rangka menanggulangi kemiskinan serta berusaha memberdayakan masyarakat secara berkelanjutan. Hingga pada tahun 2008 pelaksanaan P2KP diperluas lagi menjadi Program Nasional Pemberdayaan Masyarakat Mandiri Perkotaan (PNPM Mandiri Perkotaan). PNPM dirancang sebagai gerakan bersama yang terpadu dalam penanggulangan kemiskinan melalui proses pemberdayaan masyarakat. Pemberdayaan masyarakat memerlukan keterlibatan berbagai pihak antara lain pemerintah, kelompok ahli, dunia usaha, dan masyarakat luas.

Salah satu pemilihan lokasi sasaran PNPM Mandiri Perkotaan adalah melanjutkan kegiatan di kelurahan-kelurahan.Inti kegiatan PNPM Mandiri Perkotaan di masyarakat kelurahan/desa adalah proses menumbuhkankembangkan kemandirian dan keberlanjutan upaya-upaya penanggulangan kemiskinan dari, oleh dan untuk masyarakat, melalui proses pembelajaran dan pelembagaan nilai-nilai universal kemanusiaan (Value Based Development), prinsip-prinsip universal kemasyarakatan, serta prinsip-prinsip pembangunan berkelanjutan (sustainable development).

Indikator keberhasilan Program PNPM Mandiri Perkotaan mengacu pada indikator keberhasilan PNPM Mandiri yang sebagaimana ditetapkan dalam Pedoman Umum PNPM Mandiri yang diterbitkan Kantor Menko Kesra. Selain itu juga indikator keberhasilan PNPM Mandiri Perkotaan 2009 juga didasarkan pada Project Management Guidleine yang diterbitkan oleh Departemen Pekerjaan Umum. Meskipun PNPM tingkat desa adalah tingkat paling sederhana, namun pengukuran indikator keberhasilan tersebut hanya terbatas didasarkan pada dokumen masyarakat hasil review partisipatif tiap kelurahan/desa/kota. Sebagai sebuah lembaga yang dituntut harus transparan dan accountable, maka perlu adanya penilaian atau pengukuran kinerja lembaga tersebut sebagai upaya evaluasi diri dari rencana yang telah dibuat maupun yang akan dibuat yang akan memungkinkan jaminan adanya integritas aktivitas lembaga yang bermula 
dari top manajemen (pemerintah desa) sampai lower manajemen (masyarakat desa) dengan pendekatan konsep Integrated Performance Measurement Systems.

Dari hasil penelitian ini, diharapkan dapat memberikan manfaat kepada pihak lembaga sebagai studi penelitian yaitu :

1. Adanya pengukuran kinerja lembaga yang terintegrasi dengan indikator-indikator yang telah ditetapkan oleh Lembaga PNPM Mandiri, Pemerintah Daerah serta Departemen Pekerjaan Umum.

2. Mengetahui secara pasti nilai pencapaian kinerja lembaga.

\section{METODE PENELITIAN}

\section{Sistem Pengukuran Kinerja}

Dalam memelihara suatu aktivitas organisasi, ada 4 aspek penting yang harus diperhatikan (Simons, 2013), yaitu :

1. Tujuan dari sistem pengukuran kinerja adalah untuk mengalirkan informasi. Yang dimaksud disini adalah data, baik itu data finansial maupun non finansial yang mempengaruhi pengambilan keputusan dan tindakan manajemen.

2. Pengukuran kinerja merepresentasikan prosedur rutin yang sifatnya formal dimana informasi tersebut diolah dalam sistem komputer dalam format standar, baik dalam kertas dokumen maupun dalam sistem komputer database.

3. Pengukuran kinerja didesain khusus digunakan untuk para manager yang secara langsung berhubungan dengan informasi data.

4. Para manager menggunakan sistem pengukuran kinerja untuk memantain berbagai aktivitas organisasi.

Sistem pengukuran adalah metode sistematis untuk membentuk tujuan-tujuan bisnis bersama dengan laporan timbal balik secara berkala yang mengindikasikan kemajuan dari pencapaian tujuan-tujuan utama.

Definisi pengukuran kinerja secara sistematis disimpulkan dan dijabarkan oleh Cambrige Research Group (Neely, 1995) sebagai berikut :

1. Performance measure (ukuran performansi) yaitu suatu metrik yang digunakan untuk menghitung efisiensi dan efektifitas suatu tindakan.

2. Performance measurement (pengukuran kinerja) yaitu suatu proses perhitungan efisiensi dan efektifitas suatu tindakan.

3. Performance measurement systems (sistem pengukuran kinerja) yaitu suatu kumpulan metrik yang digunakan untuk menghitung efisiensi dan efektifitas dari suatu tindakan.

\section{Integrated Performace Measurement Systems}

Model yang dikembangkan oleh Centre for Strategic Manufacturing, dari University of Strathclyde, Glasow adalah model sistem pengukuran kinerja terintegrasi atau Integrated Performance Measurement Systems, dimana model ini memiliki karakteristik antara lain :

1. Menyusun semua aktivitas tugas dan aktivitas organisasi sesuai dengan tujuan kritis dari top level atau tingkatan atas.

2. Memberikan kendali bisnis pada seluruh bagian yang terlibat didalamnya searah dengan strategi bisnis yang dimiliki.

3. Mengarahkan program perbaikan yang searaha dengan strategi bisnis.

4. Memaksimalkan dampak dari usaha perbaikan.

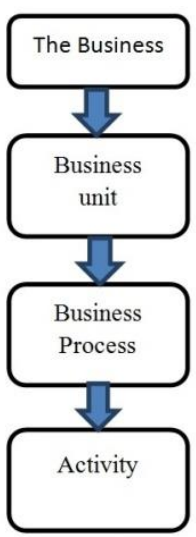

Gambar 1. Struktur model integrated performace measurement systems

Prinsip model Integrated Performance Measurement Systems secara top down, dimana telah mengakomodasikan stakeholder requirements dari bisnis induk, dengan cara ini diperoleh integrasi dan konsistensi dari sistem pengukuran kinerja dari semua tingkatan organisasi dapat dijaga. Prinsip didalam model ini bertujuan untuk memahami logika model itu sendiri yaitu :

1. Kontrol manajemen.

2. Deployment.

3. Penting.

4. Jelas.

5. Resources yang digunakan.

6. Normatif planning.

7. Pengawasan aktif.

8. Klasifikasi dan ukuran kinerja unit bisnis, proses, dan aktivitas.

\section{Scoring System dengan menggunakan Objective Matrix (OMAX).}

Objective Matrix adalah suatu sistem pengukuran produktivitas parsial yang dikembangkan untuk memantau produktivitas di tiap bagian organisasi dengan kriteria produktivitas yang sesuai dengan keberadaan bagian tersebut. Model ini melibatkan seluruh jajaran organisasi, mulai dari 
tingkat atas sampai bawah dengan harapan aktivitas seluruh anggota organisasi dapat turut menilai, memperbaiki, dan mempertahankan produktivitas.

Kelebihan-kelebihan model OMAX antara lain adalah sebagai berikut :

1. Relatif sederhana dan mudah dipahami karena indikator kinerja untuk setiap input dan output didefinisikan dengan jelas.

2. Mudah dilaksanakan dan tidak memerlukan keahlian khusus karena dapat digunakan untuk mengukur seluruh aspek kinerja yang dipertimbangkan.

3. Datanya mudah diperoleh yang merupakan kom-binasi dari pendekatan kuantitatif dan kualitatif.

4. Lebih fleksibel dengan memasukkan pertimbangan pihak manajemen dalam penentuan bobot.

Kekurangan-kekurangan model OMAX antara lain :

1. Memerlukan batasan-batasan yang jelas untuk objective score dari tiap indikator, karena penentuan objectives score-nya dilakukan secara objective.

2. Dibutuhkan suatu pengukuran yang kontinyu dan terstandar untuk mendapatkan indeks kinerja yang diharapkan.

Tahapan dalam pengimplementasian model OMAX yaitu :

1. Pendefinisian yang terdiri atas :

a. Penentuan kriteria produktivitas yang merupakan perbandingan yang menyatakan definisi untuk kerja produktif suatu unit kerja. Kriteria-kriteria ini disesuaikan dengan apa yang akan diukur. Penentuan kriteria ini harus independen dan merupakan faktor yang dapat diukur.

b. Performance (nilai pencapaian sekarang), yaitu nilai tiap produktivitas berdasarkan pengukuran terakhir.

2. Pengukuran, menggunakan skala yang terdapat pada badan matriks yang disusun oleh besaran skala pencapaian tiap-tiap kriteria. Skala yang dipakai berkisar antara 0 sampai 10 untuk terbesar. Sedangkan skala 3 dipakai untuk menunjukkan nilai produktivitas yang diukur pada awal pengukuran. Peningkatan nilai produktivitas akan disesuaikan dengan cara interpolasi.

3. Pencatatan, yang terdiri atas :

a. Nilai yang merupakan hasil perkalian dari skor pada kriteria tertentu dengan bobot kriteria tersebut.

b. Skor, yaitu hasil pengukuran yang diubah kedalam skor yang disesuaikan atau nilai skor yang disesuaikan dengan nilai produktivitas.

c. Bobot, yaitu besarnya pengaruh kriteria yang diukur terhadap nilai produktivitas yang didasarkan pada tingkat kepentingan dimana total jumlah bobit semua kriteria harus sama dengan $100 \%$ atau 1.

d. Performance indicator, yang terdiri dari current-jumlah nilai dari semua kriteria pengukuran pada saat ini (sekarang), previous-jumlah nilai pengukuran kinerja periode sebelumnya, serta indeks produktivitas (IP) yaitu perbandingan antara periode yang diukur dengan periode sebelumnya.

Struktur OMAX dapat ditabelkan dalam bentuk matrix objective seperti pada Tabel 1.

Tabel 1. Objective matrix

\begin{tabular}{|c|c|c|c|c|}
\hline kriteria & kriteria & kriteria & kriteria & $\begin{array}{c}\text { kriteria } \\
\text { produktivitas }\end{array}$ \\
\hline & & & & performance \\
\hline
\end{tabular}

\begin{tabular}{|l|l|l|l|l|}
\hline & & & & 10. \\
\hline & & & & 9. \\
\hline & & & & 8. \\
\hline & & & & 7 \\
\hline & & & & 6 \\
\hline & & & & 5 \\
\hline & & & & 4. \\
\hline & & & & 3. \\
\hline & & & & 2. \\
\hline & & & & 1. \\
\hline
\end{tabular}

\begin{tabular}{|c|c|c|c|c|}
\hline & & & & skor \\
\hline & & & & bobot \\
\hline & & & & nilai \\
\hline
\end{tabular}

\begin{tabular}{|l|l|l|c|}
\hline current & previous & index & $\begin{array}{c}\text { performance } \\
\text { indikator }\end{array}$ \\
\hline & & & \\
\hline
\end{tabular}

Nilai $8,1-10$ : artinya pencapaian kinerja suatu indikator sudah tercapai dengan target yang ditentukan oleh pihak manajemen

Nilai $6,1-8$ : artinya pencapaian indikator belum tercapai meskipun nilainya hampir mendekati target, oleh karena itu pihak manajemen perlu berhati-hati dalam menyikapi indikator tersebut dan perlu adanya perbaikan.

Nilai $\leq 6$ : artinya pencapaian benar-benar jauh dari target yang telah ditentukan, oleh sebab itu perlu adanya tindak lanjut perbaikan atau merancang usahausaha perbaikan untuk mencapai target yang diinginkan untuk periode selanjutnya.

Tabel 2. Skala penilaian pairwise comparison

\begin{tabular}{|c|c|}
\hline Nilai & Keterangan \\
\hline 1 & $\begin{array}{l}\text { elemen keputusan yang satu sama penting } \\
\text { dibandingkan dengan elemen keputusan yang } \\
\text { lain }\end{array}$ \\
\hline 3 & $\begin{array}{l}\text { elemen keputusan yang satu sedikit lebih } \\
\text { penting dibandingkan dengan elemen keputusan } \\
\text { lain }\end{array}$ \\
\hline 5 & $\begin{array}{l}\text { elemen keputusan yang satu cukup penting } \\
\text { dibandingkan dengan elemen keputusan lain }\end{array}$ \\
\hline 7 & $\begin{array}{l}\text { elemen keputusan yang satu dinilai sangat } \\
\text { penting dibandingkan dengan elemen keputusan } \\
\text { lain }\end{array}$ \\
\hline 9 & $\begin{array}{l}\text { elemen keputusan yang satu dinilai mutlak } \\
\text { sangat penting sekali dibandingkan dengan } \\
\text { elemen keputusan lain }\end{array}$ \\
\hline $\begin{array}{l}\text { kebalikan } \\
1 / 3,1 / 5, \ldots 1 / 9\end{array}$ & $\begin{array}{l}\text { nilai ini diberikan jika aktivitas i mendapat satu } \\
\text { angka dibandingkan dengan aktivitas } \mathrm{j} \text {, maka j } \\
\text { mempunyai nilai kebalikan } \mathrm{i} \text {. }\end{array}$ \\
\hline
\end{tabular}




\section{Analytical Hierarchy Process (AHP)}

AHP merupakan suatu alat bantu sistem pendukung keputusan yang digunakan untuk menyelesaikan masalah dengan multikriteria, dimana metode ini melakukan perbandingan judment pengambil keputusan secara berpasangan pada setiap level hirarki keputusannya. Metode ini juga menetapkan bobot prioritas relatif setiap elemen keputusan yang merepresentasikan intensitas prioritas keputusan itu sendiri.

Untuk menguji konsistensi para responden diberikan rumus persamaan (1).

$$
\begin{gathered}
C I=\frac{\lambda_{\text {maks }-n}}{n-1} \rightarrow C R=\frac{C I}{R I} \\
\text { dengan : } \\
C R: \text { Consistency Ratio } \\
C I: \text { Consistency Index } \\
R I: \text { Random Index }
\end{gathered}
$$

Berikut ini indeks random untuk matrik berukuran 3 sampai 10 (matrik berukuran 1 dan 2 mempunyai inkonsistensi 0 ).

\begin{tabular}{|l|c|c|c|c|c|c|c|c|}
\hline ukuran matrik & 3 & 4 & 5 & 6 & 7 & 8 & 9 & 10 \\
\hline random Index & 0,58 & 0,90 & 1,12 & 1,24 & 1,32 & 1,41 & 1,45 & 1,49 \\
\hline
\end{tabular}

Batasan diterima tidaknya konsistensi suatu matrik sebenarnya tidak ada yang baku, hanya menurut beberapa eksperimen dan pengalaman tingkat inkonsistensi sebesar 10\% kebawah adalah tingkat inkonsistensi yang masih bisa diterima. Lebih dari itu harus ada revisi penilaian dan melakukan konfirmasi kembali karena tingkat inkonsistensi yang terlalu besar dapat menjurus pada suatu kesalahan.

\section{PENGUMPULAN DATA DAN SIMULASI}

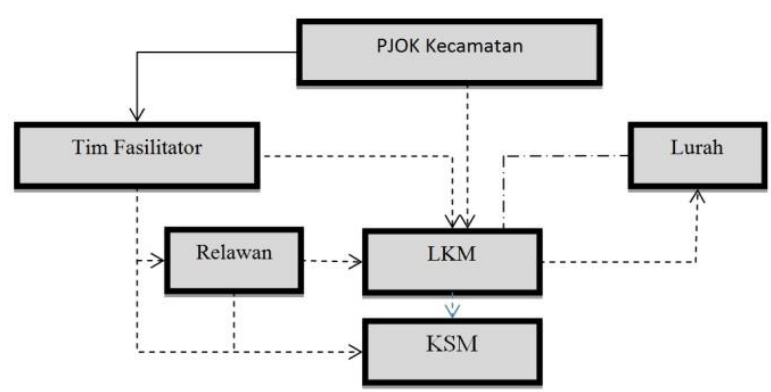

Gambar 3. Struktur Organisasi Pengelolaan PNPM Mandiri Perkotaan Tingkat Kelurahan

Keterangan :

PJOK : Penanggung Jawab Operasional Kegiatan

Tim : Tenaga Pengembangan Masyarakat P2KP

Fasilitator

Relawan : Warga setempat yang peduli membantu warga miskin di wilayahnya tanpa pamrih

LKM : Lembaga Keswadayaan Masyarakat, merupakan nama generik yang dahulu dinamakan BKM (Badan Keswadayaan Masyarakat).

KSM
Berikut simulasi hasil Kinerja PNPM Mandiri untuk Tingkat Kelurahan ditampilkan dalam Lampiran Tabel 3.

\section{PENUTUP}

Berdasarkan hasil simulasi rancangan kinerja, maka didapatkan hasil pencapaian kinerja PNPM Mandiri untuk tingkat Kelurahan sebesar 4,926 dimana masih jauh dari target yang diharapkan sehingga perlu diadakan perbaikanperbaikan di masa yang akan datang. Dengan rancangan pengukuran kinerja seperti di atas, maka hasil kinerja dapat diketahui nilai capaiannya dan bukan hanya sekedar bentuk laporan review yang tak bisa terukur secara pasti pencapaian indikator-indikator kinerjanya.

\section{DAFTAR PUSTAKA}

Bititci, U. S. (1995). Modelling of performance measurement systems in manufacturing enterprises. International journal of production economics, 42(2), 137-147.

Bititci, U. S., Suwignjo, P., \& Carrie, A. S. (2001). Strategy management through quantitative modelling of performance measurement systems. International Journal of production economics, 69(1), 15-22.

Departemen Pekerjaan Umum. (2009). Pedoman Pelaksanaan PNPMMandiri Perkotaan, Jakarta.

Neely, A., Gregory, M., \& Platts, K. (1995). Performance measurement system design: a literature review and research agenda. International journal of operations \& production management, 15(4), 80-116.

Saaty, T. L. (1990). Multicriteria Decision Making: The Analytic Hierarchy Process: Planning. Priority Setting, Ressource Allocation, Pittsburgh.

Simons, R. (2013). Performance Measurement and Control Systems for Implementing Strategy Text and Cases: Pearson New International Edition. Pearson Higher Ed.

Wahyuningsih, E.D.S. (2002). Perancangan Sistem Pengukuran Performansi Organisasi dengan Metode Integrated Performance Measurement Systems, ITS Surabaya. 


\section{Lampiran}

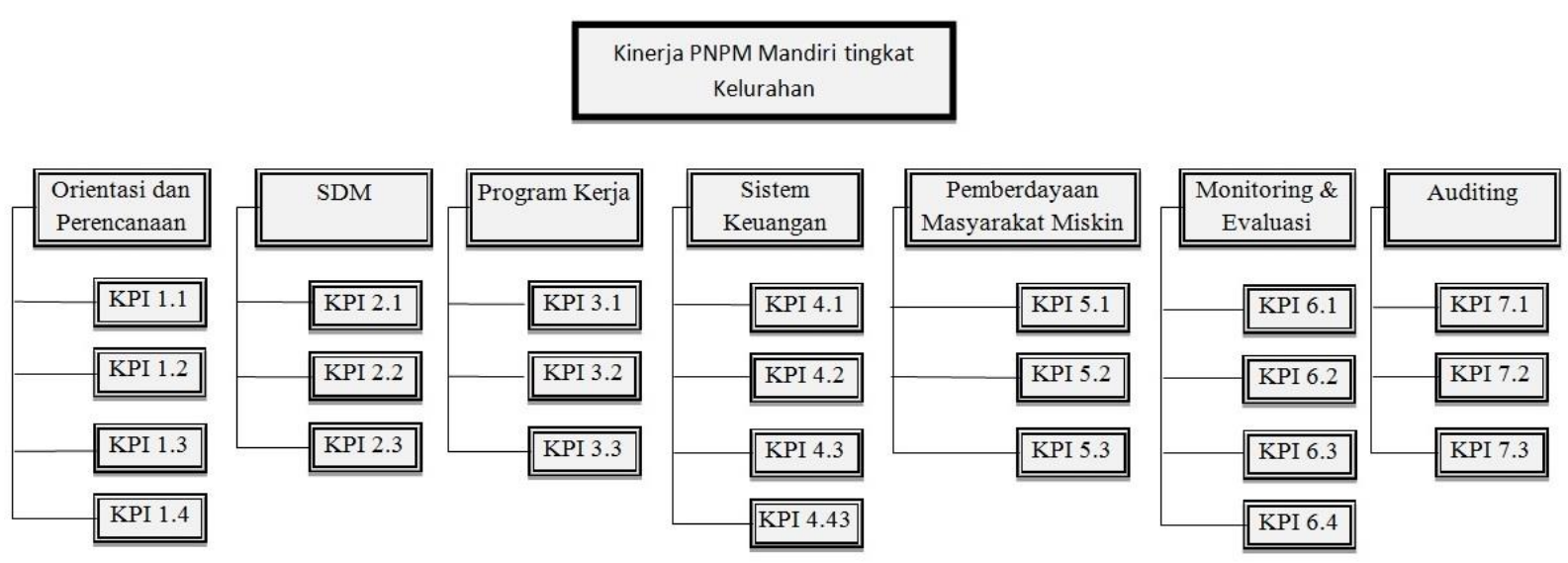

Gambar 4. Hirarki Kinerja PNPM Mandiri Perkotaan Tingkat Kelurahan

Tabel 3. Rancangan Pengukuran Kinerja PNPM Mandiri Tingkat Kelurahan

\begin{tabular}{|c|c|c|c|c|c|c|c|}
\hline \multicolumn{4}{|c|}{ Orientasi dan Perencanaan } & \multicolumn{3}{|c|}{ SDM } & \\
\hline KPI 1.1 & KPI 1.2 & KPI 1.3 & KPI 1.4 & KPI 2.1 & KPI 2.2 & KPI 2.3 & \\
\hline 99 & 80 & 100 & 80 & 30 & 40 & 50 & pencapaian \\
\hline
\end{tabular}

\begin{tabular}{|r|r|r|r|r|r|r|r|}
\hline 100 & 100 & 100 & 100 & 40 & 100 & 70 & 10 \\
\hline 98,57143 & 98,42857 & 97,14286 & 97,14286 & 38,85714 & 88,57143 & 68,57143 & 9 \\
\hline 97,14286 & 96,85714 & 94,28571 & 94,28571 & 37,71429 & 77,14286 & 67,14286 & 8 \\
\hline 95,71429 & 95,28571 & 91,42857 & 91,42857 & 36,57143 & 65,71429 & 65,71429 & 7 \\
\hline 94,28571 & 93,71429 & 88,57143 & 88,57143 & 35,42857 & 54,28571 & 64,28571 & 6 \\
\hline 92,85714 & 92,14286 & 85,71429 & 85,71429 & 34,28571 & 42,85714 & 62,85714 & 5 \\
\hline 91,42857 & 90,57143 & 82,85714 & 82,85714 & 33,14286 & 31,42857 & 61,42857 & 4 \\
\hline 90 & 89 & 80 & 80 & 32 & 20 & 60 & 3 \\
\hline 89,66667 & 82,66667 & 78,33333 & 76,66667 & 30,66667 & 16,66667 & 59,66667 & 2 \\
\hline 89,33333 & 76,33333 & 76,66667 & 73,33333 & 29,33333 & 13,33333 & 59,33333 & 1 \\
\hline 89 & 70 & 75 & 70 & 28 & 10 & 59 & 0 \\
\hline
\end{tabular}

\begin{tabular}{|c|c|c|c|c|c|c|c|}
\hline 9 & 2 & 10 & 3 & 2 & 5 & 0 & skor \\
\hline 0,011 & 0,032 & 0,027 & 0,036 & 0,013 & 0,099 & 0,054 & bobot \\
\hline 0,099 & 0,064 & 0,27 & 0,108 & 0,026 & 0,495 & 0 & value \\
\hline \multicolumn{4}{|c|}{ indeks Orientasi dan Perencanaan } & \multicolumn{3}{|c|}{ indeks SDM } & \\
\hline & & & 0,541 & & & 0,521 & \\
\hline
\end{tabular}


Tabel 3. Rancangan Pengukuran Kinerja PNPM Mandiri Tingkat Kelurahan (lanjutan 1)

\begin{tabular}{|c|c|c|c|c|c|c|c|}
\hline \multicolumn{3}{|c|}{ Program Kerja } & \multicolumn{4}{|c|}{ Sistem Keuangan } & \\
\hline KPI 3.1 & KPI 3.2 & KPI 3.3 & KPI 4.1 & KPI 4.2 & KPI 4.3 & KPI 4.4 & \\
\hline 100 & 50 & 20 & 1 & 1 & 90 & 80 & pencapaian \\
\hline
\end{tabular}

\begin{tabular}{|r|r|r|r|r|r|r|r|}
\hline 100 & 70 & 50 & 1 & 1 & 100 & 100 & 10 \\
\hline 97,14286 & 61,42857 & 45,85714 & 0,92857143 & 0,985714 & 97,14286 & 95,71429 & 9 \\
\hline 94,28571 & 52,85714 & 41,71429 & 0,85714286 & 0,971429 & 94,28571 & 91,42857 & 8 \\
\hline 91,42857 & 44,28571 & 37,57143 & 0,78571429 & 0,957143 & 91,42857 & 87,14286 & 7 \\
\hline 88,57143 & 35,71429 & 33,42857 & 0,71428571 & 0,942857 & 88,57143 & 82,85714 & 6 \\
\hline 85,71429 & 27,14286 & 29,28571 & 0,64285714 & 0,928571 & 85,71429 & 78,57143 & 5 \\
\hline 82,85714 & 18,57143 & 25,14286 & 0,57142857 & 0,914286 & 82,85714 & 74,28571 & 4 \\
\hline 80 & 10 & 21 & 0,5 & 0,9 & 80 & 70 & 3 \\
\hline 70 & 8,333333 & 20,66667 & 0,4 & 0,8 & 70 & 66,66667 & 2 \\
\hline 60 & 6,666667 & 20,33333 & 0,3 & 0,7 & 60 & 63,33333 & 1 \\
\hline 50 & 5 & 20 & 0,2 & 0,6 & 50 & 60 & 0 \\
\hline
\end{tabular}

\begin{tabular}{|c|c|c|c|c|c|c|c|}
\hline 10 & 8 & 1 & 10 & 10 & 7 & 6 & skor \\
\hline 0,002 & 0,056 & 0,041 & 0,006 & 0,032 & 0,011 & 0,072 & bobot \\
\hline 0,02 & 0,448 & 0,041 & 0,06 & 0,32 & 0,077 & 0,432 & value \\
\hline \multicolumn{3}{|c|}{ Indeks Program Kerja } & \multicolumn{4}{|c|}{ Indeks Sistem Keuangan } & \\
\hline & & 0,509 & & & & 0,889 & \\
\hline
\end{tabular}

Tabel 3. Rancangan Pengukuran Kinerja PNPM Mandiri Tingkat Kelurahan (lanjutan 2)

\begin{tabular}{|r|r|r|r|r|r|r|r|}
\hline \multicolumn{2}{|c|}{ Pemberdayaan Masy.Miskin } & \multicolumn{5}{|c|}{ Monitoring dan Evaluasi } \\
\cline { 1 - 7 } KPI 5.1 & KPI 5.2 & KPI 5.3 & KPI 6.1 & KPI 6.2 & KPI 6.3 & KPI 6.4 & \\
\hline 50 & 76 & 100 & 0,8 & 0,7 & 1 & 100 & pencapaian \\
\hline
\end{tabular}

\begin{tabular}{|c|c|c|c|c|c|c|c|}
\hline 55 & 100 & 100 & 1 & 1 & 1 & 100 & 10 \\
\hline 54,57143 & 97,14286 & 97,14286 & 0,928571 & 0,914286 & 0,985714 & 95,71429 & 9 \\
\hline 54,14286 & 94,28571 & 94,28571 & 0,857143 & 0,828571 & 0,971429 & 91,42857 & 8 \\
\hline 53,71429 & 91,42857 & 91,42857 & 0,785714 & 0,742857 & 0,957143 & 87,14286 & 7 \\
\hline 53,28571 & 88,57143 & 88,57143 & 0,714286 & 0,657143 & 0,942857 & 82,85714 & 6 \\
\hline 52,85714 & 85,71429 & 85,71429 & 0,642857 & 0,571429 & 0,928571 & 78,57143 & 5 \\
\hline 52,42857 & 82,85714 & 82,85714 & 0,571429 & 0,485714 & 0,914286 & 74,28571 & 4 \\
\hline 52 & 80 & 80 & 0,5 & 0,4 & 0,9 & 70 & 3 \\
\hline 51 & 78,33333 & 76,66667 & 0,466667 & 0,366667 & 0,766667 & 66,66667 & 2 \\
\hline 50 & 76,66667 & 73,33333 & 0,433333 & 0,333333 & 0,633333 & 63,33333 & 1 \\
\hline 49 & 75 & 70 & 0,4 & 0,3 & 0,5 & 60 & 0 \\
\hline 4 & 1 & 10 & 7 & 7 & 10 & 10 & skor \\
\hline 0,004 & 0,023 & 0,005 & 0,053 & 0,004 & 0,0024 & 0,048 & bobot \\
\hline 0,016 & 0,023 & 0,05 & 0,371 & 0,028 & 0,024 & 0,48 & value \\
\hline \multicolumn{3}{|c|}{ Indeks Pemb.Masy.Miskin } & \multicolumn{4}{|c|}{ Indeks Monitoring dan Evaluasi } & \\
\hline & & 0,089 & & & & 0,903 & \\
\hline
\end{tabular}


N Aziza, dkk / Teknika : Engineering and Sains Journal, Vol. 1, No.1, Juni 2017, 33-40

Tabel 3. Rancangan Pengukuran Kinerja PNPM Mandiri Tingkat Kelurahan (lanjutan 3)

\begin{tabular}{|c|c|c|c|}
\hline \multicolumn{3}{|c|}{ Auditing } & \\
\hline KPI 7.1 & KPI 7.2 & KPI 7.3 & \\
\hline 0,9 & 0,8 & 100 & pencapaian \\
\hline
\end{tabular}

\begin{tabular}{|r|r|r|r|}
\hline 1 & 1 & 100 & 10 \\
\hline 0,942857 & 0,942857 & 99,85714 & 9 \\
\hline 0,885714 & 0,885714 & 99,71429 & 8 \\
\hline 0,828571 & 0,828571 & 99,57143 & 7 \\
\hline 0,771429 & 0,771429 & 99,42857 & 6 \\
\hline 0,714286 & 0,714286 & 99,28571 & 5 \\
\hline 0,657143 & 0,657143 & 99,14286 & 4 \\
\hline 0,6 & 0,6 & 99 & 3 \\
\hline 0,566667 & 0,583333 & 96 & 2 \\
\hline 0,533333 & 0,566667 & 93 & 1 \\
\hline 0,5 & 0,55 & 90 & 0 \\
\hline
\end{tabular}

\begin{tabular}{|l|l|}
\hline Indeks Orientasi dan Perencanaan & 0,541 \\
\hline Indeks SDM & 0,521 \\
\hline Indeks Program Kerja & 0,509 \\
\hline Indeks Sistem Keuangan & 0,889 \\
\hline Indeks Pemb.Masy. Miskin & 0,089 \\
\hline Indeks Monitoring dan Evaluasi & 0,903 \\
\hline Indeks Auditing & 1,474 \\
\hline Indeks Performance Total & 4,926 \\
\hline
\end{tabular}

\begin{tabular}{|r|r|r|l|}
\hline 9 & 7 & 10 & skor \\
\hline 0,011 & 0,055 & 0,099 & bobot \\
\hline 0,099 & 0,385 & 0,99 & value \\
\hline
\end{tabular}

Indeks Auditing 
N Aziza, dkk / Teknika : Engineering and Sains Journal, Vol. 1, No.1, Juni 2017, 33-40

Halaman ini sengaja dikosongkan 